\title{
Sources, background and enrichment of lead and other elements: Lower Guadiana River
}

\author{
Maria J. Batista ${ }^{\text {a,* }}$, D.P.S. de Oliveira ${ }^{\mathrm{a}, \mathrm{e}}$, Maria M. Abreu ${ }^{\mathrm{b}}$, J. Locutura ${ }^{\mathrm{c}}$, T. Shepherd ${ }^{\mathrm{d}}$, J. Matos ${ }^{\mathrm{a}}$, \\ A. Bel-Lan ${ }^{\text {c }}$, L. Martins ${ }^{\text {a }}$ \\ a LNEG, Unidade de Recursos Minerais e Geofísica, Ap. 7586, 2721-866 Alfragide, Portugal \\ b ISA-Dep. Ciências do Ambiente, Univ. Técnica de Lisboa, Tapada da Ajuda, 1349-017 Lisboa, Portugal \\ ' Intituto Geologico e Minero the España, R. Rio Rosas, Madrid, Spain \\ d GEOMEDIC, Nottingham, UK \\ e CREMINER, Universidade de Lisboa, Ed. C6, Piso 3, Campo Grande, 1749-016 Lisboa, Portugal
}

\section{A R T I C L E I N F O}

\section{Article history:}

Received 18 July 2011

Received in revised form 5 July 2012

Accepted 27 August 2012

Available online $\mathrm{xxxx}$

\section{Keywords:}

Sources

Enrichment

Lead

\begin{abstract}
A B S T R A C T
The lower sector of the Guadiana River Basin, located in southern Portugal and Spain, hosts soils and plants with elevated $\mathrm{Pb}, \mathrm{Cu}$ and As near former and current mining sites. Two geogenic and two anthropogenic sources of $\mathrm{Pb}$ were identified where elevated concentrations are mostly related to the occurrence of sulphide-rich ore deposits, Volcanic Sedimentary formations and mining. These were generally reflected by the multiple regression analysis (MRA) and confirmed by isotope determinations. Nevertheless, caution was needed in interpreting statistical and isotopic results; therefore the combination of both techniques was important. Elements, such as $\mathrm{Ca}, \mathrm{Na}, \mathrm{Cu}$ and $\mathrm{As}$, show enrichment in soil developed on shale, sandstone and conglomerate of Upper Devonian age belonging to the Phyllite-Quartzite Group. Lead exhibits an enrichment in soil developed on felsic volcanic rocks from the Volcanic Sedimentary Complex (VSC) of Upper Devonian-Lower Carboniferous age, which has been identified by the relationship between topsoil median values of different lithologies and grand subsoil median values. In the same soil, $\mathrm{Fe}, \mathrm{As}, \mathrm{Co}, \mathrm{Ni}$ and $\mathrm{Cr}$ are depleted. Translocation of $\mathrm{Pb}$ to the aerial parts of plants is insignificant in all three plant species studied and analysed (Cistus ladanifer L., Thymus vulgaris, Lavandula luisieri). High Pb concentrations in soil, where Cistus ladanifer L. developed, the only representative number of species analysed, do not correspond generally to elevated $\mathrm{Pb}$ contents in plants, except near mine sites, where lower $\mathrm{pH}$ of soil, increases Pb bioavailability. The different statistical methodologies combined with $\mathrm{Pb}$ isotopic studies were successfully applied in the identification of $\mathrm{Pb}$ sources in soil and Cistus ladanifer L. plant of the Lower sector of Guadiana River basin. Therefore, rocks, mineralisations, subsoil, topsoil and plant processes were successfully integrated to understand the migration of $\mathrm{Pb}$ into the food chain.
\end{abstract}

(c) 2012 Elsevier B.V. All rights reserved.

\section{Introduction}

The Iberian Pyrite Belt (IPB) is one of the most outstanding European ore provinces, hosting one of the largest concentrations of massive sulphides in the Earth's crust and has a long and rich mining history. Due to its richness in base metals, related to the geological environment that hosts the mineralisation, the soil developed in this region contains high concentrations in the same base metals. Background values are in principle associated with the pristine soil concentrations, little affected by human activities (Cheng et al., 1999; Garrett, 2005; Levinson, 1980; Stanley and Noble, 2007; Ziaii et al., 2009). The long period of mining

\footnotetext{
* Corresponding author. Fax: +351214718980.

E-mail address: joao.batista@ineti.pt (M.J. Batista).
}

and smelting activities of IPB pose difficulties in identifying the origin of base metals in the soils. The aim of this study is to utilise different methodologies to define the sources of metals in soils and plants, by analysing different sample media ranging from rocks, mineralisations, soils and three species of plants (ladanifer L., Lavandula luisieri and Thymus vulgaris).

Volcanic hosted massive sulphide (VHMS) $\mathrm{Cu}-\mathrm{Pb}-\mathrm{Zn}$ is one typical host deposit for Pb that is common in the IPB (Tornos, 2006). The Lower sector of the Guadiana River basin in southern Portugal and Spain includes the IPB, composed mainly of metasedimentary and volcano-sedimentary rocks that host the orebodies. Lead was exploited, but it was occasionally left in dumps at the mines when market values were low (Batista et al., 2008).

Lead sulphides oxidise relatively slowly, when exposed to the surface environment, during meteoric alteration, resulting in a release of $\mathrm{Pb}$ that can then be incorporated and/or adsorbed onto clay-rich 